\title{
Mercury biomagnification in a Southern Ocean food web
}

José Seco*1,2, Sara Aparício ${ }^{3}$, Andrew S. Brierley², Paco Bustamante ${ }^{4,5}$, Filipe R. Ceia 6 , João P. Coelho ${ }^{7}$, Richard A. Philips ${ }^{8}$, Ryan A. Saunders ${ }^{8}$, Sophie Fielding ${ }^{8}$, Susan Gregory ${ }^{8,9}$, Ricardo Matias ${ }^{8}$, Miguel A. Pardal ${ }^{10}$, Eduarda Pereira $^{1}$, Gabriele Stowasser ${ }^{8}$, Geraint A. Tarling ${ }^{6}$, José C. Xavier ${ }^{6,8}$

1 Department of Chemistry and CESAM/REQUIMTE, University of Aveiro, 3810-193 Aveiro, Portugal

2 Pelagic Ecology Research Group, Scottish Oceans Institute, Gatty Marine Laboratory, University of St Andrews, St Andrews KY16 8LB, Scotland, UK

${ }^{3}$ Faculdade de Ciências e Tecnologia, Universidade Nova de Lisboa, Caparica, Portugal

${ }^{4}$ Littoral Environnement et Sociétés (LIENSs), UMR 7266 CNRS - La Rochelle Université, 2 rue Olympe de Gouges, 17000 La Rochelle, France

${ }^{5}$ Institut Universitaire de France (IUF), 1 rue Descartes 75005 Paris, France

${ }^{6}$ University of Coimbra, Marine and Environmental Sciences Centre, Department of Life Sciences, Calçada Martim de Freitas, 3000-456 Coimbra, Portugal.

${ }^{7}$ CESAM - Centre for Environmental and Marine Studies, Department of Biology, University of Aveiro, Campus Universitário de Santiago, 3810-193 Aveiro, Portugal

${ }^{8}$ British Antarctic Survey, NERC, High Cross, Madingley Road, Cambridge CB3 OET, UK

${ }^{9}$ Government of South Georgia \& the South Sandwich Islands, Stanley, Falkland Islands

${ }^{10}$ CFE - Centre for Functional Ecology, Department of Life Sciences, University of Coimbra, Calçada Martim de Freitas, 3000-456 Coimbra, Portugal

${ }^{*}$ Corresponding author: José Seco

E-mail address: jose@uc.pt

Abstract

Biomagnification of mercury $(\mathrm{Hg})$ in the Scotia Sea food web of the Southern Ocean was examined using the stable isotope ratios of nitrogen $\left(\delta^{15} \mathrm{~N}\right)$ and carbon $\left(\delta^{13} \mathrm{C}\right)$ as proxies for trophic level and feeding habitat, respectively. Total $\mathrm{Hg}$ and stable isotopes were measured in samples of particulate organic matter (POM), zooplankton, squid, myctophid fish, notothenioid fish and seabird tissues collected in two years (austral summers 2007/08 and 2016/17). Overall, there was extensive overlap in $\delta^{13} \mathrm{C}$ values across taxonomic groups suggesting similarities in habitats, with the exception of the seabirds, which showed some differences, possibly due to the type of tissue analyzed (feathers instead of muscle). $\delta^{15} \mathrm{~N}$ showed increasing enrichment across groups in the order POM to zooplankton to squid to myctophid fish to notothenioid fish to seabirds. There were significant differences in $\delta^{13} \mathrm{C}$ and $\delta^{15} \mathrm{~N}$ values among species within taxonomic groups, reflecting inter-specific variation in diet. $\mathrm{Hg}$ concentrations increased with trophic level, with the lowest values in POM $\left(0.0005 \pm 0.0002 \mu \mathrm{g} \mathrm{g}^{-1}\right.$ $\mathrm{dw}$ ) and highest values in seabirds (3.88 $\pm 2.41 \mu \mathrm{g} \mathrm{g}^{-1}$ in chicks of brown skuas Stercorarius antarcticus). Hg concentrations tended to be lower in 2016/17 than in 2007/08 for mid-trophic level species (squid and fish), but the opposite was found for top predators (i.e. seabirds), which had higher levels in the 2016/17 samples. This may reflect an interannual shift in the Scotia Sea marine food web, caused by the reduced availability of a key prey species, Antarctic krill Euphausia superba. In 2016/17, seabirds would have been forced to feed on higher trophic-level prey, such as myctophids, that have higher Hg burdens. These results suggest that changes in 
the food web are likely to affect the pathway of mercury to Southern Ocean top predators.

Capsule: Changes in foodweb dynamics influence $\mathrm{Hg}$ bioaccumulation in top predators.

Keywords: Trophic magnification slope; Stable isotopes; Contaminants; Antarctica; Polar.

\section{Introduction}

Antarctica and the Southern Ocean comprise a globally unique ecosystem characterised by cold environmental conditions. Due to its isolation and ofteninhospitable weather, much of the region has remained relatively untouched by direct human activity, such that it is often considered by the scientific community as a natural laboratory (Walton, 2013). Given the absence of any local manufacturing industry, anthropogenic mercury $(\mathrm{Hg})$ emissions from within Antarctica are negligible. Nevertheless, there is long-range dispersal of $\mathrm{Hg}$ from regions outside Antarctica, and relatively high concentrations can be found in Southern Ocean waters (Cossa et al., 2011). The global distillation process (Wania and Mackay, 1996) leads to atmospheric transportation of a range of volatile and semi-volatile pollutants in the form of vapour. $\mathrm{Hg}$ is transported by atmospheric currents in the form of $\mathrm{Hg}^{0}$ to the polar regions where it condenses and precipitates in rain or snow (O'Driscoll et al., 2005). Indeed, Antarctica can be considered a gigantic fridge where atmospherically transported pollutants are stored in the ice fields (Eisele et al., 2008), becoming bioavailable when glaciers and icebergs melt (Mastromonaco et al., 2017). Moreover, recent studies have shown that vegetation in the polar environments can play an important role in the uptake of Hg0. Plus, Atmospheric Mercury Depletion Events (AMDE) occurring during springtime at polar sunrise (Ebinghaus et al., 2002) are known to increase the deposition fluxes of atmospheric $\mathrm{Hg}$ (Brooks et al., 2008; Elizalde, 2017), and 
katabatic winds can redistribute $\mathrm{Hg}$ within Antarctica, carrying it from the high Antarctic plateau towards coastal areas (Bargagli, 2016; Bromwich1989, 1989).

Among pollutants, $\mathrm{Hg}$ is one of the most toxic elements, particularly its organic form (methyl- $\left.\mathrm{Hg},\left[\mathrm{CH}_{3} \mathrm{Hg}\right]^{+}\right)$(Clarkson, 1992). Due to its high affinity for proteins and hence retention within tissues (Bloom, 1992), $\mathrm{Hg}$ is highly bioaccumulative in organisms over the course of their lives. It also biomagnifies along food webs from plankton up to top predators ((Ackerman et al., 2014; Coelho et al., 2013; Dehn et al., 2006). Methyl- $\mathrm{Hg}$ is assimilated more efficiently by organisms than inorganic $\mathrm{Hg}$, and is accumulated rather than excreted (Monteiro et al., 1996). Hg concentrations are therefore higher in the upper trophic levels of food webs, especially those in aquatic systems which tend be highly size-structured (Heneghan et al., 2019), and may become very toxic for large, long-lived top predators (Goutte et al., 2014; Tartu et al., 2014; Tavares et al., 2013). Indeed, some Southern Ocean predators have particularly high $\mathrm{Hg}$ concentrations. For example, wandering albatross, Diomedea exulans, which can live to over 50 years (Lecomte et al., 2010) have amongst the highest reported feather $\mathrm{Hg}$ concentrations (up to $73.42 \mu \mathrm{g} \mathrm{g}^{-1}$ ) of any seabird, reflecting a high degree of exposure to this metal (Anderson et al., 2009; Cherel et al., 2018; Tavares et al., 2013; Thompson et al., 1998).

Indices of the enrichment of stable isotopes of nitrogen $\left(\delta^{15} \mathrm{~N}\right)$ and carbon $\left(\delta^{13} \mathrm{C}\right)$ provide proxies for the trophic level and carbon source (habitat) of consumers, respectively (Cherel and Hobson, 2007; Stowasser et al., 2012). ${ }^{15} \mathrm{~N}$ becomes enriched in tissues in a consistent way in food webs, on average by $+3.4 \%$ per trophic level (Minagawa and Wada, 1984). ${ }^{13} \mathrm{C}$ is enriched at a lower rate (on average by +1 $\%$ per trophic level) but gives a useful indicator of feeding habitat; this indicates, for example, the relative contributions of feeding inshore versus offshore, in shallow water 
versus deep water, or in particular water masses given the broad latitudinal gradients in the Southern Ocean (Hobson et al., 1994). Although some studies have reported $\mathrm{Hg}$ concentrations both in low trophic level organisms and top predators in the Southern Ocean (e.g. Anderson et al. 2009), none have evaluated Hg biomagnification across multiple levels in the food web, from particulate organic matter (POM) to apex predators, using $\delta^{15} \mathrm{~N}$ to determine trophic position.

Antarctic krill (Euphausia superba; hereafter krill) is a key component of the food web in the Southern Ocean (Murphy et al., 2007), and can be the main trophic link between primary producers and predators (Everson, 2000; Xavier and Peck, 2015; Xavier et al., 2018). However, recent studies have shown that there are alternative trophic pathways in periods and regions of low Antarctic krill abundance. These include, for example, copepods to mesopelagic fish to high predators (Ballerini et al., 2014; Murphy et al., 2007; 2013; Saunders et al., 2019). These alternative pathways are unlikely to support the same biomass of predators given the greater number of steps in the food chain over which energy can be lost (Barnes et al., 2010). Decreases in the reproductive performance of top predators, including seabirds and pinnipeds, in low-krill years in the Scotia Sea region suggests that these alternative pathways cannot entirely replace those involving krill in maintaining very large predator populations (Croxall et al., 1999; Xavier et al., 2003; 2017). In the present study, we measured total $\mathrm{Hg}$ concentrations, $\delta^{13} \mathrm{C}$ and $\delta^{15} \mathrm{~N}$ values in a suite of species from different trophic levels to elucidate $\mathrm{Hg}$ 120 biomagnification in components of the food web in the Scotia Sea, one of the most 121 productive regions of the Southern Ocean (Atkinson et al., 2001). POM and tissues 122 from key functional organisms from multiple trophic levels were analysed, including zooplankton, squid, mesopelagic fish (myctophids), necto-benthic fish (notothenioids), 
and seabirds. The field sampling was undertaken in two austral summers, 9 years apart (December 2007 to February 2008 and December 2016 to January 2017). The main objectives were to 1) describe $\mathrm{Hg}$ dynamics in the Scotia Sea food web, 2) evaluate $\mathrm{Hg}$ biomagnification-rates, and, 3) evaluate possible differences in the $\mathrm{Hg}$ pathway from POM to top predators in different sampling years.

Materials and Methods

Field sampling

Samples were collected during oceanographic research cruises on board the RRS James Clark Ross around the islands of South Georgia (5417'S, $\left.36^{\circ} 30 \mathrm{~W}\right)$ during the austral summers of 2007/08 and 2016/17 (cruises JR177 and JR16003 respectively). Background concentrations of $\mathrm{Hg}$ in $\mathrm{POM}$ were determined from water samples collected in Niskin bottles deployed on a CTD (conductivity, temperature, depth) rosette fired at the depth of the chlorophyll a maximum (which ranged from 30 to $76 \mathrm{~m}$ ) and at $500 \mathrm{~m}$. The depths were chosen to enable comparison of the likely

140 highest concentrations of POM with the lower values expected below the euphotic zone. POM was obtained by vacuum-filtering $5 \mathrm{~L}$ of water through glass fibre filters

142 (GF/F Whatman, $47 \mathrm{~mm}$ ) during JR16003. Zooplankton, squid and myctophid fish species were collected using either an 8 or $25 \mathrm{~m}^{2}$ mouth-opening Rectangular

144 Midwater Trawl [RMT8 - mesh size reducing from $4.5 \mathrm{~mm}$ to $2.5 \mathrm{~mm}$ in the cod end to 145 collect zooplankton; RMT25 - mesh size reducing from $8 \mathrm{~mm}$ to $4.5 \mathrm{~mm}$ in the cod end 146 to collect mesopelagic fish and squid (Roe and Shale, 1979)]. Both systems 147 incorporated two separate nets that could be opened and closed remotely on 148 command at different depths. Myctophid fish and squid were identified using 149 appropriate taxonomic keys (Gon and Heemstra, 1990; Hulley, 1981; Nesis, 1987; 
150 Xavier and Cherel, 2009). Sub-samples were then frozen individually in separate 151 plastic bags at $-20^{\circ} \mathrm{C}$ for later laboratory analyses. Zooplankton species were identified following Boltovskoy (1999). Sub-samples of these species were either preserved in plastic bags at $-20^{\circ} \mathrm{C}(\mathrm{JR} 16003)$ or in glass vials in $70 \%$ ethanol (JR177).

Notothenioid fish were also obtained from South Georgia waters in the austral summer of 2016/17. They were caught by the Fishing Vessel (FV) Sil during research survey SG17. Samples were obtained from bottom trawls using a FP120 trawl net with a standard steel bobbin rig. Whenever possible, samples were identified on board but, in some cases, identification was not possible at sea and was performed later at the laboratory. Individuals were frozen at sea at $-20^{\circ} \mathrm{C}$ for later laboratory processing. rather than adults because $\mathrm{Hg}$ and stable isotope ratios in their tissues reflect those of food consumed during the chick-rearing period (Blévin et al., 2013; Moreno et al., 2016). Furthermore, all of these feathers are grown by chicks over the same period, so $\mathrm{Hg}$ concentrations and stable isotope ratios reflect similar time periods and can be compared directly (Carravieri et al., 2014a).

\section{Laboratory procedures}

POM filters were digested with $\mathrm{HNO}_{3} 4 \mathrm{M}$ for determination of $\mathrm{Hg}$ concentrations

170 (for details, see Pato et al., 2010). Analyses were performed at the University of Aveiro by cold-vapour atomic fluorescence spectrometry (CV-AFS) using a PSA model Merlin

17210.023 equipped with a PSA model 10.003 detector, with tin chloride as a reducing 173 agent $(2 \%$ in $10 \% \mathrm{HCl})$ following Pato et al., (2010). The limit of quantification of this 174 technique was $0.02 \mu \mathrm{g} \mathrm{L}^{-3}$. 

preserved in $70 \%$ ethanol were first dried for $72 \mathrm{~h}$ at ambient temperature to remove ethanol, and then freeze-dried for $48 \mathrm{~h}$ (Fort et al., 2014). Samples of squid and fish muscle tissue (freeze-dried for $>24 \mathrm{~h}$ ) were chosen for analysis since muscle is the most important tissue in terms of transfer of $\mathrm{Hg}$ to predators (Bustamante et al., 2006; Cipro et al., 2018). Feathers were first cleaned to remove surface contaminants using a 2:1 chloroform:methanol solution followed by two methanol rinses, and then oven dried for $48 \mathrm{~h}$ at $50^{\circ} \mathrm{C}$.

Dried individual zooplankton, muscle samples and feathers were homogenized to powder and analysed for total $\mathrm{Hg}$ by thermal decomposition atomic absorption spectrometry with gold amalgamation, using a LECO AMA-254 (Advanced Mercury Analyser) at the University of Aveiro, following Coelho et al., (2008). Analytical quality control was performed using certified reference materials (CRMs): for zooplankton we used TORT-2 and TORT-3 with recoveries of $87 \pm 3 \%$ and $90 \pm 8 \%$, respectively; for squid we used NIST 2976, ERM-CE278K and TORT-3 with recoveries of $85 \pm 7 \%, 92$ $\pm 5 \%$ and $93 \pm 8 \%$, respectively; for myctophids we used DORM-4 and ERM-BB422 with recoveries of $96 \pm 13 \%$ and $100 \pm 4 \%$, respectively; for notothenioid fish we used ERM-BB422 with recovery of $98 \pm 7 \%$, and for seabirds we used TORT-3 with recovery of $99 \pm 3 \%$. Sample analyses were repeated in duplicate or triplicate until the relative standard deviation was $<10 \%$ for multiple aliquots. The limit of detection for this analytical method was $0.01 \mathrm{ng}$ of absolute mercury.

As lipid is enriched in ${ }^{13} \mathrm{C}$ relative to other tissue components (DeNiro and

197 Epstein, 1977), lipids were extracted from fish muscle. An aliquot of approximately 10 $\mathrm{mg}$ of fine muscle-tissue powder was agitated with $4 \mathrm{ml}$ of cyclohexane for $1 \mathrm{~h}$. Next, the sample was centrifuged for $5 \mathrm{~min}$ at $4000 \mathrm{~g}$, and the supernatant containing lipids 
was discarded. Due to small masses and low sample numbers it was not possible to remove lipids from zooplankton, nor to pool samples, so stable isotope ratios were corrected according to Post et al., (2007). As squid muscle and bird feathers have low lipid content, no delipidation was applied. Low lipid content was checked by considering $\mathrm{C} / \mathrm{N}$ mass ratios, which were always below 4.0 (squid -3.91 and seabirds $-3.46)$.

Approximately $0.4 \mathrm{mg}$ of dry subsample homogenates were weighed out into tin cups. A continuous flow mass spectrometer (Thermo Scientific Delta V Advantage) was coupled to an elemental analyzer (Thermo Scientific Flash EA 1112), at either the LIENSs or MAREFOZ laboratories, to measure $\delta^{13} \mathrm{C}$ and $\delta^{15} \mathrm{~N}$ values. Stable isotope ratios are expressed using standard $\delta$ notation relative to carbonate Vienna PeeDee

Belemnite and atmospheric nitrogen. The internal laboratory standard is acetanilide. Observed analytical errors were $<0.10 \%$ for both $\delta^{13} \mathrm{C}$ and $\delta^{15} \mathrm{~N}$ values at both facilities.

Statistical analysis

All analyses were performed using R software v. 3.4.2 (R Core Team, 2013).

217 Distributions of $\mathrm{Hg}$ concentrations and $\delta^{13} \mathrm{C}$ and $\delta^{15} \mathrm{~N}$ values within samples were 218 tested for normality using Shapiro-Wilk normality test, and homogeneity of variance 219 was tested using Bartlett's test. Wilcoxon rank and Kruskal-Wallis tests were used to compare $\mathrm{Hg}, \delta^{13} \mathrm{C}$ and $\delta^{15} \mathrm{~N}$ values among trophic groups (zooplankton, squid, myctophid fish, notothenioid fish, and seabirds) and species, followed by a Dunn's

222 multiple comparisons test. T-test or Mann-Whitney were used to compare $\mathrm{Hg}, \delta^{13} \mathrm{C}$ and $\delta^{15} \mathrm{~N}$ values between $2007 / 08$ and 2016/17. Linear regressions were examined

224 between $\log _{10} \mathrm{Hg}$ and $\delta^{15} \mathrm{~N}$ values as a tool to evaluate the trophic magnification slope 
(TMS) (Lavoie et al., 2013). All values are presented as means \pm SD. The significance level for statistical analyses was $\alpha=0.05$.

227

\section{Results}

$\delta^{13} \mathrm{C}$ as a proxy of habitat

$\delta^{13} \mathrm{C}$ values for samples collected in $2007 / 08$ and $2016 / 17$ are given in Tables

2311 and 2 respectively. Among whole zooplankton, $\delta^{13} \mathrm{C}$ values ranged from $-25.64 \%$

232 in krill (Euphausia superba) to $-20.48 \%$ in the amphipod Parandania boecki. For secondary consumers (myctophid fish and squid), $\delta^{13} \mathrm{C}$ values in muscle tissue ranged

234 from -25.67 \%o (Electrona antarctica) to -20.15\% (Slosarczykovia circumantarctica), 235 while for notothenioid fish, it was from $-23.80 \%$ in Champsocephalus gunnari to $20.60 \%$ in Dissostichus eleginoides. Values of $\delta^{13} \mathrm{C}$ in seabird feathers tended to be higher (i.e. more enriched in ${ }^{13} \mathrm{C}$ ), ranging from $-22.82 \%$ in Antarctic prions

238 (Pachyptila desolata) to $-15.24 \%$ in brown skuas (Stercorarius antarcticus) (Table 1). There were only significant differences in $\delta^{13} \mathrm{C}$ values between seabirds and the other trophic groups within each sampling year (Kruskal-Wallis test, $H=50.23, p<0.0001$, in 2007/08; $\mathrm{H}=63.69, \mathrm{p}<0.0001$ in $2016 / 17$ ). There were no differences between the other groups.

Within the seabird group, brown skuas had significantly higher $\delta^{13} \mathrm{C}$ values than

244 northern giant petrels (Macronectes halli) in 2007/08 (Kruskal-Wallis test, $\mathrm{H}=15.932$,

$245 p=0.007$; Dunn's multiple comparisons test, $p=0.0028 ;$ Table 1). In 2016/17, significant differences among seabirds were also detected (Kruskal-Wallis test, $\mathrm{H}=$

247 22.552, $p<0.0001$; Table 2) and these were mainly driven by the higher value in brown skuas compared with Antarctic prions (Dunn's multiple comparisons test, $p=$ 
0.0013), and blue petrels Halobaena caerulea (Dunn's multiple comparisons test, $p=$

250

251

252

253

254

255

256

257

258

259

260

261

262

263

264

265

266

267

268

269

270

271

272

273 $0.0144)$.

Within the notothenioid fish (Kruskal-Wallis test, $\mathrm{H}=24.794, \mathrm{p}=0.0002$; Table 2), N. gibberifrons had significant higher $\delta^{13} \mathrm{C}$ than $C$. gunnari (Dunn's multiple comparisons test, $p=0.0002$ ) and $P$. guntheri (Dunn's multiple comparisons test, $p=$ $0.00013)$. No significant differences in $\delta^{13} \mathrm{C}$ were observed between any myctophid fish in 2007/08 (Kruskal-Wallis test, $H=16.141, p=0.061$; Table 1) whereas, in $2016 / 17, \delta^{13} \mathrm{C}$ values were significantly lower in E. antarctica than in Gymnoscopelus nicholsi (Kruskal-Wallis test, $\mathrm{H}=16.751, \mathrm{p}=0.0049$; Dunn's multiple comparisons test, $p=0.0115 ;$ Table 2).

$\delta^{13} \mathrm{C}$ values were not significantly different between sampling years either in squid (Wilcoxon rank test, $W=3, p=0.25$, in 2007/08; $W=0, p=0.2$ in 2017) or zooplankton (Kruskal-Wallis test, $H=5.1538, p=0.741$, in 2007; $H=19.19, p=0.1388$ in 2016/17; Tables 1 \& 2).

$\delta^{15} \mathrm{~N}$ as a proxy of trophic structure

$\delta^{15} \mathrm{~N}$ values for each species in 2007/08 and 2016/17 are given in Tables 1 and 2 , respectively. $\delta^{15} \mathrm{~N}$ was significantly higher in seabirds (7.69 \% in Antarctic prions to $15.50 \%$ in wandering albatrosses (Diomedea exulans) and notothenioid fish (only in 2016/17; $7.71 \%$ in Patagonotothen guntheri to $14.41 \%$ in $N$. rossii) than in the other taxonomic groups (Kruskal-Wallis test, $H=59.184, p<0.0001, H=80.284, p<0.0001$ for birds and fish respectively). Moreover, values decreased from myctophid fish (6.69 $\%$ in E. antarctica to $10.91 \%$ in $G$. opisthopterus), to squid (5.68 \%o in $S$. circumantarctica to $9.38 \%$ in Galiteuthis glacialis) and then zooplankton $(1.73 \%$ in E. superba to $8.81 \%$ in Gigantocypris sp.). 

species (Kruskal-Wallis test, $\mathrm{H}=20.979, \mathrm{p}=0.0008$, Table 1). Wandering albatrosses had significantly higher $\delta^{15} \mathrm{~N}$ than black-browed albatrosses (Thalassarche melanophris; Dunn's multiple comparisons test, $p=0.0043)$, grey-headed albatrosses (Thalassarche chrysostoma; Dunn's multiple comparisons test, $p=0.0340$ ) and southern giant petrels (M. giganteus; Dunn's multiple comparisons test, $p=0.0049)$. In 2016/17, there were also differences among seabird species (Kruskal-Wallis test, $\mathrm{H}=21.756, \mathrm{p}=0.001$ Table 2) with Antarctic prions having significantly lower $\delta^{15} \mathrm{~N}$ values than brown skuas (Dunn's multiple comparisons test, $p=0.0251$ ) and greyheaded albatrosses (Dunn's multiple comparisons test, $p=0.0202$ ).

$\delta^{15} \mathrm{~N}$ values also differed significantly among species of notothenioid fish 285 (Kruskal-Wallis test, $\mathrm{H}=25.847, \mathrm{p}<0.001$, Table 2) with $C$. gunnari and $P$. guntheri 286 having significantly lower values than $N$. gibberifrons (Dunn's multiple comparisons test, $p=0.0045 ; p=0.0273$ ) and $D$. eleginoides (Dunn's multiple comparisons test, $p$ $=0.0029 ; p=0.0124$ ). No significant differences in $\delta^{15} \mathrm{~N}$ were detected between species of myctophid fish (Kruskal-Wallis test, $\mathrm{H}=7.996, \mathrm{p}=0.238$, in 2007/08; $\mathrm{H}=$ 12.888, $p=0.244 ;$ Tables $1 \& 2$ ) and squid (Wilcoxon rank test, $W=11, p=0.393$, in 2007/08; $W=6, p=0.200$ in 2016/17; Tables $1 \&$ 2) in either of the sampling years. Significant differences in $\delta^{15} \mathrm{~N}$ were only observed between two species of zooplankton (Kruskal-Wallis test, $\mathrm{H}=20.03, \mathrm{p}=0.010$; Table 2), E. superba and $P$. boecki in 2007/08 (Dunn's multiple comparisons test, $p=0.0032$ ).

Mercury concentrations

In both sampling years, seabirds had the highest $\mathrm{Hg}$ concentrations among the analysed species. In seabirds, $\mathrm{Hg}$ concentrations ranged from $0.12 \mathrm{\mu g} \mathrm{g}^{-1}$ in Antarctic 
prions to $7.17 \mathrm{\mu g} \mathrm{g}^{-1}$ in brown skuas; the next highest values were in myctophid fish

300

301

302

303

304

305

306

307

308

309

310

311

312

313

314

315

316

317

318

319

320

321

322

323

$\left(0.025 \mu \mathrm{g} \mathrm{g}^{-1}\right.$ in Krefftichthys anderssoni to $0.352 \mu \mathrm{g} \mathrm{g}^{-1}$ in $\mathrm{G}$. nicholsi) and notothenioid fish $\left(0.007 \mu \mathrm{g} \mathrm{g}^{-1}\right.$ in $C$. gunnari to $0.343 \mu \mathrm{g} \mathrm{g}^{-1}$ in $N$. rossii), squid $\left(0.012 \mu \mathrm{g} \mathrm{g}^{-1}\right.$ in $S$. circumantarctica to $0.066 \mu \mathrm{g} \mathrm{g}^{-1}$ in $\mathrm{G}$. glacialis) and zooplankton $\left(0.006 \mu \mathrm{g} \mathrm{g}^{-1}\right.$ in $E$. superba to $0.141 \mathrm{Mg} \mathrm{g}^{-1}$ in $P$. boecki). As expected, POM had the lowest $\mathrm{Hg}$ concentrations $\left(0.0005 \pm 0.0002 \mu \mathrm{g} \mathrm{g}^{-1}\right)$. Highly significant differences were found in total $\mathrm{Hg}$ concentrations between taxonomic groups (including POM), within both sampling years (Kruskal-Wallis test, $H=59.75, p<0.0001$, in 2007/08; $H=82.42$, $p$ $<0.0001$ in 2016/17)

Significant differences in $\mathrm{Hg}$ concentrations were observed among seabird species both in 2007/08 (Kruskal-Wallis test, $\mathrm{H}=22.621, \mathrm{p}=0.0003$; Table 1) and 2016/17 (Kruskal-Wallis test, $\mathrm{H}=24.175, \mathrm{p}=0.0005$; Table 2). In 2007/08, wandering albatrosses showed the highest concentrations, followed by brown skuas, greyheaded albatrosses, black-browed albatrosses, southern giant petrels and northern giant petrels. In 2016/17, brown skuas had the highest concentrations followed by northern giant petrels, southern giant petrels, black-browed albatrosses, grey-headed albatrosses, blue petrels and Antarctic prions.

In notothenioid fish, there were highly significant differences between species (Kruskal-Wallis test, $\mathrm{H}=27.795, \mathrm{p}<0.0001$ ). In particular, C. gunnari had significantly lower $\mathrm{Hg}$ concentrations than $N$. gibberifrons, $N$. rossii and D. eleginoides (Dunn's multiple comparisons test, $p=0.0004 ; p=0.0009, p=0.0028 ;$ Table 2). Myctophids showed differences between the species in both sampling years (Kruskal-Wallis test, $H=15.317, p=0.018$, in 2007/08; $H=13.52, p=0.019$ in 2016/17; Tables 1 \& 2), with G. nicholsi having a higher $\mathrm{Hg}$ concentration than $P$. bolini (Dunn's multiple comparisons test, $p=0.0368$ in 2007/08; $p=0.0375$ in 2016/17) and $K$. anderssoni 
324 (Dunn's multiple comparisons test, $p=0.0325$ in 2007/08; $p=0.0381$ in 2016/17).

325 There were no significant differences in $\mathrm{Hg}$ concentrations between squid species in

326 either year (Wilcoxon rank test, $W=15, p=0.057$, in 2007/08; $W=4, p=0.8000$ in

327 2016/17) nor among zooplankton species in 2007/8 (Kruskal-Wallis test, $\mathrm{H}=7.4231$,

$328 p=0.492)$. However, in $2016 / 17$, there were significant differences between species

329 in 2016/2017 (Kruskal-Wallis test, $\mathrm{H}=20.445, \mathrm{p}=0.0088$ ).

330 Significant positive linear regressions were found between $\log _{10} \mathrm{Hg}$

331 concentrations and $\delta^{15} \mathrm{~N}$ values across all species in both years $\left(Y=0.2112^{*} X-\right.$

332 2.8088, $r^{2}=0.7904, p<0.0001$ in 2007/8; $Y=0.2451^{*} X-3.0363, r^{2}=0.8419, p<$

3330.0001 in 2016/17).

334

335

Comparison between years

Five of the eight seabird species were sampled in both study years (brown

skuas, grey-headed and black-browed albatrosses, northern and southern giant petrels). With regards to $\delta^{15} \mathrm{~N}$, significant differences between $2007 / 08$ and $2016 / 17$

values were only found for northern giant petrels (t-test, $t_{8}=3.907, p=0.0045$ ), whereas $\delta^{13} \mathrm{C}$, values differed in most seabirds with the exception of northern giant petrels (t-test, t9 $=1.693, p=0.1246) . \mathrm{Hg}$ concentrations were generally higher in $2016 / 17$ than in $2007 / 08$, but this was significant only for northern giant petrels (Mann Whitney test, $U=0, p=0.0079)$ and southern giant petrels $\left(t_{8}=6.322, p<0.005\right)$.

In myctophids, five out of the seven species were caught in both sampling years

(E. antarctica, G. nicholsi, G. braueri, K. anderssoni and P. bolini). $\delta^{15} \mathrm{~N}$ and $\delta^{13} \mathrm{C}$ were similar in all species between the two periods. Unlike seabirds, Hg concentrations were lower in $2016 / 17$ than in $2007 / 08$, and significantly so in the case of E. antarctica (Mann Whitney test $U=45, p=0.002$ ). Six species of zooplankton were caught in both 
sampling years (E. triacantha, Parandania boecki, Gigantocypris sp., E. superba, Thysanoessa sp., Themisto gaudichaudii). No significant differences in $\delta^{15} \mathrm{~N}, \delta^{13} \mathrm{C}$ or Hg were detected between any zooplankton species between 2007/08 and 2016/17. There were significant positive correlations between $\log _{10} \mathrm{Hg}$ concentrations and $\delta^{15} \mathrm{~N}$ values in the species that were sampled in both years $\left(Y=0.2028^{*} X-\right.$ 2.6008, $r^{2}=0.8138, p<0.0001$ in 2007/8; $Y=0.2782^{*} X-3.0960, r^{2}=0.9314, p<$ 0.0001 in 2016/17) (Figure 1). The slope of the relationship was significantly higher in $2016 / 17(0.2782)$ than $2007 / 08(0.2028)$ (ANOVA, $\left.F_{1,110}=9.716, P=0.0023.\right)$

\section{Discussion}

A number of studies have used nitrogen stable isotope values $\left(\delta^{15} \mathrm{~N}\right)$ to contextualise the biomagnification of $\mathrm{Hg}$ within food webs in different ecosystems 361 (Cabana and Rasmussen, 1994; Lavoie et al., 2013). However, to the best of our knowledge, this study is the first to evaluate $\mathrm{Hg}$ bioaccumulation from POM to top predators in a Southern Ocean food web.

Influence of feeding habitat

The first assumption when evaluating food web structure and links using stable isotope ratios is that all the analysed species share broadly the same environment. This assumption is required to rule out the potential for any spatial variation in baseline $\delta^{15} \mathrm{~N}$ in apparent trophic level within geographically distinct ecosystems (Chouvelon et al., 2012). Ecosystem connectedness can be determined using $\delta^{13} \mathrm{C}$ as a proxy for

371 habitat (Kelly, 2000), and all taxonomic groups in our study had broadly similar $\delta^{13} \mathrm{C}$

372 values (Tables 1 and 2). The greatest differences in $\delta^{13} \mathrm{C}$ values were observed in 373 seabirds, which is to be expected as feathers are more enriched in ${ }^{13} \mathrm{C}$ than blood, 
374 muscle and internal organs (Cherel et al., 2014; Kelly, 2000), and we assert that the

375 distinct seabird $\delta^{13} \mathrm{C}$ values are a consequence of the use of different tissues rather

376 than any spatial separation. This assertion is backed up by tracking data during chick-

377 rearing, which shows that all the sampled seabird species forage broadly in the same areas where the myctophids, squid and zooplankton were caught [wandering albatrosses (Jiménez et al., 2015); southern giant petrels and northern giant petrels (Granroth-Wilding and Phillips, 2018a); brown skuas (Carneiro et al., 2014); Antarctic prions and blue petrel (Navarro et al., 2013); black-browed albatrosses and greyheaded albatrosses (Phillips et al., 2004b)]. As expected, there were small differences in $\delta^{13} \mathrm{C}$ values among some species within taxonomic groups, indicating a limited degree of divergence in foraging habits (e.g. feeding depth), but this has no material effect on our conclusions about trophic level based on $\delta^{15} \mathrm{~N}$. Hg concentrations throughout the sampled food web were not influenced by differences in habitat utilization (inferred from the $\delta^{13} \mathrm{C}$ values), as our analysis reflects a single regional system in the Scotia Sea in the vicinity of South Georgia.

Trophic structure in relation to mercury concentrations

Our combined field sampling provided two snapshots, 9 years apart, of $\mathrm{Hg}$ concentrations in the Scotia Sea food web. Values of Hg were lowest in POM, followed by zooplankton, which as a group exhibited some degree of variation. This is not surprising since the zooplankton species examined range from predominantly herbivorous Antarctic krill (Quetin and Ross, 1991) to predators such as Themisto gaudichaudii (Havermans et al., 2019). Squid and myctophid fish link zooplankton to the top predators (seabirds) and, in terms of $\mathrm{Hg}$ dynamics, exhibit some degree of variation between individuals and species in $\mathrm{Hg}$ concentrations [for more details see 
399 (Seco et al., 2020a; 2020b)]. Generally, the highest $\mathrm{Hg}$ concentrations were found in 400 predators higher in the food web (notothenioid fish and seabirds). Our first clear result 401 is therefore that total $\mathrm{Hg}$ concentration increases with trophic level (reflected by $\delta^{15} \mathrm{~N}$ ).

402 This relationship was expected as a result of $\mathrm{Hg}$ biomagnification through food webs, 403 and has previously been reported by other studies in the Antarctic region (Anderson 404 et al., 2009).

Trophic links to the two groups of top predators analysed here, seabirds and notothenioid fish (the latter taxa are sometimes considered to be mesopredators, as they can themselves be predated by larger species), can be considered as two parallel paths in the Scotia Sea food web, because both groups of top predators occupy similar trophic positions (see Tables 1 and 2). However, our results reveal that the seabirds can be differentiated into three distinct groups with characteristic $\mathrm{Hg}$ levels: wandering albatrosses and brown skuas had the highest $\mathrm{Hg}$ concentrations of all seabird species (1.556 - $7.173 \mu \mathrm{g} \mathrm{g}^{-1}$; grey-headed albatrosses, black-browed albatrosses, southern giant petrels and northern giant petrels, had intermediate $\mathrm{Hg}$ levels $(0.1216-2.952$ $\left.\mu \mathrm{g} \mathrm{g}^{-1}\right)$, and Antarctic prions and blue petrel had the lowest $\mathrm{Hg}$ levels $(0.1198-0.9591$ $\left.\mu \mathrm{g} \mathrm{g}^{-1}\right)$. This is a classic effect of diet on Hg levels in seabirds: seabirds that feed on zooplankton have lower concentrations than fish- and squid- eating species (Bocher et al., 2003; Carravieri et al., 2014b). Wandering albatrosses feed on higher trophic

418 level prey, mainly large fish and squid (Moreno et al., 2016), which our study shows had relatively high $\mathrm{Hg}$ concentrations. Brown skuas have a diverse diet, feeding on Antarctic fur seal Arctocephalus gazella carrion (including placentae), other seabirds and occasionally fish or squid which they obtain via kleptoparasitism (Phillips et al. 2004a). Carravieri et al., (2014b) showed that brown skua chicks at Kerguelen have higher $\mathrm{Hg}$ feather concentrations than the adults, probably because their diet consists 
424 mainly of blue petrels, whereas adults during the non-breeding period consume a more

425 diverse diet, including marine prey. High diet diversity probably also explains the high

426 variability in $\mathrm{Hg}$ and $\delta^{15} \mathrm{~N}$ in grey-headed albatrosses and black-browed albatrosses,

427 which feed on fish, squid and crustaceans (Prince, 1980a). Northern giant petrels and 428 southern giant petrels are more generalist, feeding both on carrion on land (from 429 Antarctic fur seals and penguins) and Antarctic krill, squid and other seabirds (Hunter, 430 1983). Additionally, both species present sex differences in feeding habits, with males 431 predominantly scavenging during the early-mid breeding season, whereas females 432 mostly forage at sea (Gonzáles-Solís et al., 2000; Granroth-Wilding and Phillips, 2018b). The smaller seabirds in our study, Antarctic prions and blue petrel, feed mainly 434 on zooplankton, including Antarctic krill (Prince, 1980b). They are therefore exposed to lower $\mathrm{Hg}$ concentrations than seabirds that are piscivorous or teuthophageous seabirds, as reported in other breeding areas (Blévin et al. 2013, Carravieri et al. 2014). Thus, the smaller bird species have $\mathrm{Hg}$ concentrations in the same range as some fish and squid species, probably also because chicks have had only a short exposure period, which reduces the potential for $\mathrm{Hg}$ bioaccumulation too. species. Hg concentrations were lower in C. gunnari than in all the other species, which is consistent with the reported results for these fish at the Kerguelen Islands 443 (Bustamante et al., 2003; Cipro et al., 2018). These differences only partly reflect 444 trophic level, as $\delta^{15} \mathrm{~N}$ was similar in $C$. gunnari and $P$. guntheri. Nor does the 445 discrepancy appear to mirror what is known about diet, as both species are considered 446 to feed mostly on euphausiids and amphipods (Collins et al., 2008; di Prisco et al., 447 1991). Furthermore, the influence of body size can be discounted, as $C$. gunnari were on average $67 \mathrm{~mm}$ bigger than $P$. guntheri, and larger fish tend to have higher $\mathrm{Hg}$ 
concentrations in species with similar growth rates (Dang and Wang, 2012; Gewurtz et al., 2011). Instead, the low Hg concentrations seem more likely to relate to the highly specialized physiological characteristics of C. gunnari, including the absence of haemoglobin (Sidell and O'Brien, 2006), which is associated with lower metabolic rates (Johnston and Camm, 1987). However, this would need to be confirmed by further studies.

As in seabirds, the notothenioid fish species at higher trophic levels had higher Hg concentrations. D. eleginoides feeds mostly on fish, squid and crustaceans (Collins et al., 2010; 2007; Seco et al., 2015). In contrast, N. gibberifrons and N. rossii feed on diverse prey from algae to amphipods, euphausiids and other fish (Casaux et al., 1990), which would also explain the large variability in their $\delta^{15} \mathrm{~N}$ values. The diet of $C$. aceratus is dominated by crustaceans and fish (Reid et al., 2007). Together, these guild-specific results highlight the important role of diet in $\mathrm{Hg}$ bioaccumulation. The slope of the linear regression between $\log _{10}(\mathrm{Hg})$ concentration and $\delta^{15} \mathrm{~N}$ values, also known as the trophic magnification slope (TMS), is an indicator of $\mathrm{Hg}$ biomagnification potential in a food web (Lavoie et al., 2013; Yoshinaga et al., 1992). Hg TMS can be influenced not only by food web dynamics but also by habitat characteristics (Lavoie et al., 2013). At lower latitude regions, slower growth rates and slower $\mathrm{Hg}$ excretion rates, due to colder temperatures, could lead to greater biomagnification of $\mathrm{Hg}(0.21 \pm 0.07$; Lavoie et al., 2013) that the at higher latitudes, where higher primary productivity and growth rates (Gross et al., 1988; Pauly 1998) may lead to lower TMS (0.16 \pm 0.08 ; Lavoie et al., 2013). TMS values for the Scotia

471 Sea ecosystem were 0.267 for $2007 / 08$ and 0.200 for $2016 / 17$, which are both within

472 the range of those previously reported for polar regions (Lavoie et al., 2013). 
Interannual variation in mercury concentration

When comparing species collected in both sampling years, $\mathrm{Hg}$ concentrations in the mid trophic-level groups (squid and myctophid) were lower in 2016/17 than in 2007/08, as reported in detail by Seco et al. (2020b; 2020a). In contrast, Hg concentrations were higher in the seabirds sampled in $2016 / 17$ than in $2007 / 08$, which is the opposite pattern to the mid trophic-level species (Seco et al., 2020a). This was unexpected as the $\mathrm{Hg}$ body burdens of predators should, in theory, reduce if there is less bioavailable $\mathrm{Hg}$ in their prey (Atwell et al., 1998). A plausible explanation is that there was a change in the main trophic pathway between years (Ward et al., 2010). Differences in $\mathrm{Hg}$ levels in producers as well as changes in the productivity and food web structure can directly influence $\mathrm{Hg}$ concentration in top predators (Ward et al., 2010). The Scotia Sea food web is centred on Antarctic krill (Murphy et al., 2007), the abundance of which can determine the reproductive success and survival of dependent predators (Grünbaum and Veit, 2003; Lynnes et al., 2004; Seyboth et al., 2016). In years with low Antarctic krill abundance, predators switch to alternative food sources, particularly myctophid fish or squid (Murphy et al., 2007; Mills et al., 2020). In our study, Antarctic krill had amongst the lowest Hg concentrations, suggesting that in situations when less krill is available predators, a switch to alternative prey with higher $\mathrm{Hg}$ burdens (Figure. 2B) will result in predators being subjected to greater levels of $\mathrm{Hg}$ bioaccumulation. Abundance of Antarctic krill based on acoustic surveys to the northwest of South Georgia was relatively low in 2016/17 (BAS, unpublished data) when compared with previous years (Fielding et al., 2014). Our Hg data possibly illustrates the knock-on effect of variable Antarctic krill abundance on food web dynamics, particularly the effect on higher predators that cascade through the food web. This is of particular interest in light of studies that suggest there is a long-term 

decline in abundance of Antarctic krill in the Scotia Sea (Atkinson et al., 2019; Hill et al., 2019; Rintoul et al., 2018). In years of low Antarctic krill abundance, predators not only have to cope with the stress of reduced prey availability, but with a concomitant

502 increase in $\mathrm{Hg}$ exposure. Our results highlight that changes in food web dynamics, 503 particularly temporal switches between krill-based and non-krill-based trophic 504 pathways, are likely to be important in the transport of $\mathrm{Hg}$ between mid-trophic levels and apex predators in the Southern Ocean.

506

\section{Acknowledgments}

508 We thank the officers, crew and scientists aboard RSS James Clark Ross during 509 cruises JR177 and JR16003 for their assistance in collecting samples. We also thank 510 Giulia Pompeo for her help with the $\mathrm{Hg}$ analysis. We are grateful to G. Guillou from

511 the "Plateforme Analyses Isotopiques" of LIENSs for his assistance during stable 512 isotope analyses at the University of La Rochelle. We acknowledge the financial 513 support of the Portuguese Foundation for the Science and Technology (FCT/MCTES) 514 through a PhD grant to José Seco (SRFH/PD/BD/113487) and CESAM 515 (UIDP/50017/2020+UIDB/50017/2020), through national funds. The Institut

516 Universitaire de France is acknowledged for its support to P. Bustamante as a Senior 517 Member. This research was also within strategic program of MARE (MARE 518 UID/MAR/04292/2020). The work is a contribution to the Ecosystems component of 519 the British Antarctic Survey Polar Science for Planet Earth Programme, funded by the 520 Natural Environment Research Council, which is part of UK Research and Innovation.

\section{References}


Ackerman, J.T., Eagles-Smith, C.A., Heinz, G., La Cruz, De, S.E.W., Takekawa, J.Y., Miles, A.K., Adelsbach, T.L., Herzog, M.P., Bluso-Demers, J.D., Demers, S.A., Herring, G., Hoffman, D.J., Hartman, C.A., Willacker, J.J., Suchanek, T.H., Schwarzbach, S.E., Maurer, T.C., 2014. Mercury in birds of San Francisco BayDelta, California-Trophic pathways, bioaccumulation, and ecotoxicological risk to avian reproduction: U.S. Geological Survey Open-File Report. doi:10.3133/ofr20141251

Anderson, O.R.J., Phillips, R.A., McDonald, R.A., Shore, R.F., Mcgill, R.A.R., Bearhop, S., 2009. Influence of trophic position and foraging range on mercury levels within a seabird community. Mar. Ecol. Prog. Ser. 375, 277-288. doi:10.3354/meps07784

Atkinson, A., Hill, S.L., Pakhomov, E.A., Siegel, V., Reiss, C.S., Loeb, V.J., Steinberg, D.K., Schmidt, K., Tarling, G.A., Gerrish, L., Sailley, S.X.V.F., 2019. Krill (Euphausia superba) distribution contracts southward during rapid regional warming. Nature Climate Change 9, 142-147. doi:10.1038/s41558-018-0370-z Atkinson, A., Whitehouse, M.J., Priddle, J., Cripps, G.C., Ward, P., Brandon, M.A., 2001. South Georgia, Antarctica: a productive, cold water, pelagic ecosystem†. Mar. Ecol. Prog. Ser. 216, 279-308. doi:10.3354/meps216279

Atwell, L., Hobson, K.A., Weich, H.E., 1998. Biomagnification and bioaccumulation of mercury in an arctic marine food web: insights from stable nitrogen isotope analysis. Can. J. Fish. Aquat. Sci. 55, 1114-1121. doi:10.1139/f98-001

Ballerini, T., Hofmann, E.E., Ainley, D.G., Daly, K., Marrari, M., Ribic, C.A., Smith, W.O., Jr, Steele, J.H., 2014. Productivity and linkages of the food web of the southern region of the western Antarctic Peninsula continental shelf. Prog. Oceanogr 122, 10-29. doi:10.1016/j.pocean.2013.11.007

Bargagli, R., 2016. Atmospheric chemistry of mercury in Antarctica and the role of cryptogams to assess deposition patterns in coastal ice-free areas.

Chemosphere 163, 202-208. doi:10.1016/j.chemosphere.2016.08.007

Barnes, C., Maxwell, D., Reuman, D.C., Jennings, S., 2010. Global patterns in predator-prey size relationships reveal size dependency of trophic transfer efficiency. Ecology 91, 222-232. doi:10.1890/08-2061.1

Blévin, P., Carravieri, A., Jaeger, A., Chastel, O., Bustamante, P., Cherel, Y., 2013. Wide Range of Mercury Contamination in Chicks of Southern Ocean Seabirds. PLoS ONE 8, e54508-11. doi:10.1371/journal.pone.0054508

Bloom, N.S., 1992. On the chemical form of mercury in edible fish and marine invertebrate tissue. Can. J. Fish. Aquat. Sci. 49, 1010-1017. doi:10.1139/f92-113

Bocher, P., Caurant, F., Miramand, P., Cherel, Y., Bustamante, P., 2003. Influence of the diet on the bioaccumulation of heavy metals in zooplankton-eating petrels at Kerguelen archipelago, Southern Indian Ocean. Polar Biol. 26, 759-767. doi:10.1007/s00300-003-0552-6

Boltovskoy, D., 1999. South Atlantic Zooplankton. Backhuys Publishers, Leide, Netherland.

Bromwich, D.H., 1989, 1989. An extraordinary katabatic wind regime at Terra Nova Bay, Antarctica. Mon. Wea. Rev. 117, 688-695. doi:10.1175/1520-0493

Brooks, S., LINDBERG, S., SOUTHWORTH, G., ARIMOTO, R., 2008. Springtime atmospheric mercury speciation in the McMurdo, Antarctica coastal region. Atmos Environ. 42, 2885-2893. doi:10.1016/j.atmosenv.2007.06.038

Bustamante, P., Bocher, P., Cherel, Y., Miramand, P., Caurant, F., 2003. Distribution of trace elements in the tissues of benthic and pelagic fish from the Kerguelen Islands. Sci. Total Environ. 313, 25-39. doi:10.1016/S0048-9697(03)00265-1 
Bustamante, P., Lahaye, V., Durnez, C., Churlaud, C., Caurant, F., 2006. Total and organic $\mathrm{Hg}$ concentrations in cephalopods from the North Eastern Atlantic waters: Influence of geographical origin and feeding ecology. Sci. Total Environ. 368, 585-596. doi:10.1016/j.scitotenv.2006.01.038

Cabana, G., Rasmussen, J.B., 1994. Modelling food chain structure and contaminant bioaccumulation using stable nitrogen isotopes. Nature 372, 255-257. doi:10.1038/372255a0

Carneiro, A.P.B., Manica, A., Phillips, R.A., 2014. Foraging behaviour and habitat use by brown skuas Stercorarius lonnbergi breeding at South Georgia. Mar Biol 161, 1755-1764. doi:10.1007/s00227-014-2457-z

Carravieri, A., Bustamante, P., Churlaud, C., Fromant, A., Cherel, Y., 2014a. Moulting patterns drive within-individual variations of stable isotopes and mercury in seabird body feathers: implications for monitoring of the marine environment. Mar Biol 161, 963-968. doi:10.1007/s00227-014-2394-x

Carravieri, A., Cherel, Y., Blévin, P., Brault-Favrou, M., Chastel, O., Bustamante, P., 2014b. Mercury exposure in a large subantarctic avian community. Environ. Pollut. 190, 51-57. doi:10.1016/j.envpol.2014.03.017

Casaux, R.J., Mazzotta, A.S., Barrera-Oro, E.R., 1990. Seasonal aspects of the biology and diet of nearshore nototheniid fish at Potter Cove, South Shetland Islands, Antarctica. Polar Biol. 11, 63-72. doi:10.1007/BF00236523

Cherel, Y., Barbraud, C., Lahournat, M., Jaeger, A., Jaquemet, S., Wanless, R.M., Phillips, R.A., Thompson, D.R., Bustamante, P., 2018. Accumulate or eliminate? Seasonal mercury dynamics in albatrosses, the most contaminated family of birds. Environ. Pollut. 241, 124-135. doi:10.1016/j.envpol.2018.05.048

Cherel, Y., Hobson, K.A., 2007. Geographical variation in carbon stable isotope signatures of marine predators: a tool to investigate their foraging areas in the Southern Ocean. Mar. Ecol. Prog. Ser. 329, 281-287.

Cherel, Y., Jaquemet, S., Maglio, A., Jaeger, A., 2014. Differences in $\delta^{13} \mathrm{C}$ and $\delta^{15} \mathrm{~N}$ values between feathers and blood of seabird chicks: implications for noninvasive isotopic investigations. Mar Biol 161, 229-237. doi:10.1007/s00227-0132314-5

Chouvelon, T., Spitz, J., Caurant, F., Mèndez-Fernandez, P., Chappuis, A., Laugier, F., Le Goff, E., Bustamante, P., 2012. Revisiting the use of $\delta^{15} \mathrm{~N}$ in meso-scale studies of marine food webs by considering spatio-temporal variations in stable isotopic signatures. The case of an open ecosystem: the Bay of Biscay (northeast Atlantic). Prog. Oceanogr 101, 92-105. doi:10.1016/j.pocean.2012.01.004

Cipro, C.V.Z., Cherel, Y., Bocher, P., Caurant, F., Miramand, P., Bustamante, P., 2018. Trace elements in invertebrates and fish from Kerguelen waters, southern Indian Ocean. Polar Biol. 41, 175-191. doi:10.1007/s00300-017-2180-6

Clarkson, T.W., 1992. Mercury: Major Issues in Environmental Health. Environ. Health Perspect. 100, 31-38. doi:10.1289/ehp.9310031

Coelho, J.P., Mieiro, C.L., Pereira, M.E., Duarte, A.C., Pardal, M.A., 2013. Mercury biomagnification in a contaminated estuary food web: Effects of age and trophic position using stable isotope analyses. Mar. Pollut. Bull. 69, 110-115. doi:10.1016/j.marpolbul.2013.01.021

Coelho, J.P., Reis, A.T., Ventura, S., Pereira, M.E., Duarte, A.C., Pardal, M.A., 2008. Pattern and pathways for mercury lifespan bioaccumulation in Carcinus maenas. Mar. Pollut. Bull. 56, 1104-1110. doi:10.1016/j.marpolbul.2008.03.020

Collins, M.A., Brickle, P., Brown, J., Belchier, M., 2010. Provided for non-commercial research and educational use only. Not for reproduction, distribution or 

commercial use., 1st ed, Advances in Marine Biology. Elsevier Ltd. doi:10.1016/S0065-2881(10)58004-0

Collins, M.A., Ross, K.A., Belchier, M., Reid, K., 2007. Distribution and diet of juvenile Patagonian toothfish on the South Georgia and Shag Rocks shelves (Southern Ocean). Mar Biol 152, 135-147.

Collins, M.A., Shreeve, R.S., Fielding, S., Thurston, M.H., 2008. Distribution, growth, diet and foraging behaviour of the yellow-fin notothen Patagonotothen guntheri (Norman) on the Shag Rocks shelf (Southern Ocean). J Fish Biol 72, 271-286. doi:10.1111/j.1095-8649.2007.01711.x

Cossa, D., Heimbürger, L.-E., Lannuzel, D., Rintoul, S.R., Butler, E.C.V., Bowie, A.R., Averty, B., Watson, R.J., Remenyi, T., 2011. Mercury in the Southern Ocean. Geochim. Cosmochim. Acta 75, 4037-4052. doi:10.1016/j.gca.2011.05.001

Croxall, J.P., Reid, K., Prince, P.A., 1999. Diet, provisioning and productivity responses of marine predators to differences in availability of Antarctic krill. Mar. Ecol. Prog. Ser.

Dang, F., Wang, W.-X., 2012. Why mercury concentration increases with fish size? Biokinetic explanation. Environ. Pollut. 163, 192-198. doi:10.1016/j.envpol.2011.12.026

Dehn, L.-A., Follmann, E.H., Thomas, D.L., Sheffield, G.G., Rosa, C., Duffy, L.K., O'Hara, T.M., 2006. Trophic relationships in an Arctic food web and implications for trace metal transfer. Sci. Total Environ. 362, 103-123. doi:10.1016/j.scitotenv.2005.11.012

DeNiro, M.J., Epstein, S., 1977. Mechanism of carbon isotope fractionation associated with lipid synthesis. Sci 197, 261-263. doi:10.1126/science.327543

di Prisco, G., Maresca, B., Tota, B., 1991. Biology of Antarctic fish. Springer, Berlin.

Ebinghaus, R., Kock, H.H., Temme, C., Einax, J.W., Löwe, A.G., Richter, A., Burrows, J.P., Schroeder, W.H., 2002. Antarctic Springtime Depletion of Atmospheric Mercury. Environ. Sci. Technol. 36, 1238-1244. doi:10.1021/es015710z

Eisele, F., Davis, D.D., Helmig, D., Oltmans, S.J., Neff, W., Huey, G., Tanner, D., Chen, G., Crawford, J., Arimoto, R., Buhr, M., Mauldin, L., Hutterli, M., Dibb, J., Blake, D., Brooks, S.B., Johnson, B., Roberts, J.M., Wang, Y., Tan, D., Flocke, F., 2008. Antarctic Tropospheric Chemistry Investigation (ANTCI) 2003 overview. Atmos Environ. 42, 2749-2761. doi:10.1016/j.atmosenv.2007.04.013

Elizalde, M.R., 2017. Sources and fate of methylmercury in the Southern Ocean : use of model seabirds and mercury stable isotopes. Universite de La Rochelle. Everson, I., 2000. Krill: Biology, Ecology and Fisheries. Blackwell Science, London. Fielding, S., Watkins, J.L., Trathan, P.N., Enderlein, P., Waluda, C.M., Stowasser, G., Tarling, G.A., Murphy, E.J., 2014. Interannual variability in Antarctic krill (Euphausia superba) density at South Georgia, Southern Ocean: 1997-2013. ICES J Mar Sci 71, 2578-2588. doi:10.1093/icesjms/fsu104

Fort, J., Robertson, G.J., Grémillet, D., Traisnel, G., Bustamante, P., 2014. Spatial Ecotoxicology: Migratory Arctic Seabirds Are Exposed to Mercury Contamination While Overwintering in the Northwest Atlantic. Environ. Sci. Technol. 48, 1156011567. doi:10.1021/es504045g

Gewurtz, S.B., Bhavsar, S.P., Fletcher, R., 2011. Influence of fish size and sex on mercury/PCB concentration: Importance for fish consumption advisories. Environ Int 37, 425-434. doi:10.1016/j.envint.2010.11.005 
Gonzáles-Solís, J., Croxall, J.P., Wood, A.G., 2000. Foraging partitioning between giant petrels Macronectes spp. and its relationship with breeding population changes at Bird Island, South Georgia. Mar. Ecol. Prog. Ser. 204, 279-288. doi:10.3354/meps204279

Goutte, A., Barbraud, C., Meillère, A., Carravieri, A., Bustamante, P., Labadie, P., Budzinski, H., Delord, K., Cherel, Y., Weimerskirch, H., Chastel, O., 2014. Demographic consequences of heavy metals and persistent organic pollutants in a vulnerable long-lived bird, the wandering albatross. Proc. Biol. Sci. 281, 20133313. doi:10.1098/rspb.2013.3313

Granroth-Wilding, H.M.V., Phillips, R.A., 2018a. Segregation in space and time explains the coexistence of two sympatric sub-Antarctic petrels. Ibis 161, 101116. doi:10.1111/ibi.12584

Granroth-Wilding, H.M.V., Phillips, R.A., 2018b. Segregation in space and time explains the coexistence of two sympatric sub-Antarctic petrels. Ibis 161, 101116. doi:10.1111/ibi.12584

Grünbaum, D., Veit, R.R., 2003. Black-browed albatrosses foraging on Antarctic krill: density-dependence through local enhancement? Ecology 84, 3265-3275. doi:10.1890/01-4098

Havermans, C., Auel, H., Hagen, W., Held, C., Ensor, N.S., Tarling, G.A., 2019. Predatory zooplankton on the move: Themisto amphipods in high-latitude marine pelagic food webs, 1st ed, Advances in Marine Biology. Elsevier Ltd. doi:10.1016/bs.amb.2019.02.002

Heneghan, R.F., Hatton, I.A., Galbraith, E.D., 2019. Climate change impacts on marine ecosystems through the lens of the size spectrum. Emerging Topics in Life Sciences 3, 233-243. doi:10.1042/ETLS20190042

Hill, S.L., Atkinson, A., Pakhomov, E.A., Siegel, V., 2019. Evidence for a decline in the population density of Antarctic krill Euphausia superba Dana, 1850 still stands. A comment on Cox et al. J. Crustac. Biol. 39, 316-322. doi:10.1093/jcbiol/ruz004

Hobson, K.A., Piatt, J.F., Pitocchelli, J., 1994. Using stable isotopes to determine seabird trophic relationships. J Anim Ecol 786-798.

Hunter, S., 1983. The food and feeding ecology of the giant petrels Macronectes halli and M. giganteus at South Georgia. J Zool 200, 521-538. doi:10.1111/j.14697998.1983.tb02813.x

Jiménez, S., Domingo, A., Brazeiro, A., Defeo, O., Wood, A.G., Froy, H., Xavier, J.C., Phillips, R.A., 2015. Sex-related variation in the vulnerability of wandering albatrosses to pelagic longline fleets. Anim Conserv 19, 281-295. doi:10.1111/acv.12245

Johnston, I.A., Camm, J.P., 1987. Muscle structure and differentiation in pelagic and demersal stages of the Antarctic teleost Notothenia neglecta. Mar Biol 94, 183190. doi:10.1007/BF00392930

Kelly, J.F., 2000. Stable isotopes of carbon and nitrogen in the study of avian and mammalian trophic ecology. Can. J. Zool. 78, 1-27. doi:10.1139/z99-165

Lavoie, R.A., Jardine, T.D., Chumchal, M.M., Kidd, K.A., Campbell, L.M., 2013. Biomagnification of Mercury in Aquatic Food Webs: A Worldwide Meta-Analysis. Environ. Sci. Technol. 47, 13385-13394. doi:10.1021/es403103t

Lecomte, V.J., Sorci, G., Cornet, S., Jaeger, A., Faivre, B., Arnoux, E., Gaillard, M., Trouvé, C., Besson, D., Chastel, O., Weimerskirch, H., 2010. Patterns of aging in the long-lived wandering albatross. Proc. Natl. Acad. Sci. U.S.A. 107, 63706375. doi:10.1073/pnas.0911181107 
Lynnes, A.S., Reid, K., Croxall, J., 2004. Diet and reproductive success of Adélie and chinstrap penguins: linking response of predators to prey population dynamics. Polar Biol. 27, 544-554. doi:10.1007/s00300-004-0617-1

Mastromonaco, M.G.N., Gårdfeldt, K., Assmann, K.M., Langer, S., Delali, T., Shlyapnikov, Y.M., Zivkovic, I., Horvat, M., 2017. Speciation of mercury in the waters of the Weddell, Amundsen and Ross Seas (Southern Ocean). Mar. Chem. 193, 20-33. doi:10.1016/j.marchem.2017.03.001

Minagawa, M., Wada, E., 1984. Stepwise enrichment of $15 \mathrm{~N}$ along food chains: further evidence and the relation between $\delta 15 \mathrm{~N}$ and animal age. Geochim. Cosmochim. Acta 48, 1135-1140. doi:10.1016/0016-7037(84)90204-7

Moreno, R., Stowasser, G., Mcgill, R.A.R., Bearhop, S., Phillips, R.A., 2016. Assessing the structure and temporal dynamics of seabird communities: the challenge of capturing marine ecosystem complexity. J Anim Ecol 85, 199-212. doi:10.1111/1365-2656.12434

Murphy, E.J., Hofmann, E.E., Watkins, J.L., Johnston, N.M., Piñones, A., Ballerini, T., Hill, S.L., Trathan, P.N., Tarling, G.A., Cavanagh, R.A., Young, E.F., Thorpe, S.E., Fretwell, P., 2013. Comparison of the structure and function of Southern Ocean regional ecosystems: The Antarctic Peninsula and South Georgia. J Marine Syst 109-110, 22-42.

Murphy, E.J., Watkins, J.L., Trathan, P.N., Reid, K., Meredith, M.P., Thorpe, S.E., Johnston, N.M., Clarke, A., Tarling, G.A., Collins, M.A., Forcada, J., Shreeve, R.S., Atkinson, A., Korb, R., Whitehouse, M.J., Ward, P., Rodhouse, P.G., Enderlein, P., Hirst, A.G., Martin, A.R., Hill, S.L., Staniland, I.J., Pond, D.W., Briggs, D.R., Cunningham, N.J., Fleming, A.H., 2007. Spatial and temporal operation of the Scotia Sea ecosystem: a review of large-scale links in a krill centred food web. Phil. Trans. R. Soc. B 362, 113-148. doi:10.1098/rstb.2006.1957

Navarro, J., Votier, S.C., Aguzzi, J., Chiesa, J.J., Forero, M.G., Phillips, R.A., 2013. Ecological Segregation in Space, Time and Trophic Niche of Sympatric Planktivorous Petrels. PLoS ONE 8, e62897-12. doi:10.1371/journal.pone.0062897

O'Driscoll, N.J., Rencz, A., Lean, D., 2005. The biogeochemistry and fate of mercury in the environment. Met lons Biol Syst 43, 221-238. doi:10.1201/9780824751999.ch9

Pato, P., Otero, M., Válega, M., Lopes, C.B., Pereira, M.E., Duarte, A.C., 2010. Mercury partition in the interface between a contaminated lagoon and the ocean: The role of particulate load and composition. Mar. Pollut. Bull. 60, 1658-1666. doi:10.1016/j.marpolbul.2010.07.004

Phillips, R.A., Phalan, B., Forster, I.P., 2004a. Diet and long-term changes in population size and productivity of brown skuas Catharacta antarctica lonnbergi at Bird Island, South Georgia. Polar Biol. 27, 1-7. doi:10.1007/s00300-004-06331

Phillips, R.A., Silk, J.R.D., Phalan, B., Catry, P., Croxall, J.P., 2004b. Seasonal sexual segregation in two Thalassarche albatross species: competitive exclusion, reproductive role specialization or foraging niche divergence? Proc. R. Soc. Lond. B 271, 1283-1291. doi:10.1098/rspb.2004.2718

Post, D.M., Layman, C.A., Arrington, D.A., Takimoto, G., Quattrochi, J., Montaña, C.G., 2007. Getting to the fat of the matter: models, methods and assumptions for dealing with lipids in stable isotope analyses. Oecologia 152, 179-189. doi:10.1007/s00442-006-0630-x 
Prince, P.A., 1980a. The food and feeding ecology of Grey-headed Albatross Diomedea chrysostoma and Black-browed Albatross D. melanophris. Ibis 122, 476-488. doi:10.1111/j.1474-919X.1980.tb00902.x

Prince, P.A., 1980b. The food and feeding ecology of Blue petrel (Halobaena caerulea) and Dove prion (Pachyptila desolata). J Zool 190, 59-76. doi:10.1111/j.1469-7998.1980.tb01423.x

Quetin, L.B., Ross, R.M., 1991. Behavioral and Physiological Characteristics of the Antarctic Krill, Euphausia superba. Amer. Zool. 31, 49-63.

Reid, W.D.K., Clarke, S., Collins, M.A., Belchier, M., 2007. Distribution and ecology of Chaenocephalus aceratus (Channichthyidae) around South Georgia and Shag Rocks (Southern Ocean). Polar Biol. 30, 1523-1533. doi:10.1007/s00300-0070313-z

Rintoul, S.R., Chown, S.L., DeConto, R.M., England, M.H., Fricker, H.A., MassonDelmotte, V., Naish, T.R., Siegert, M.J., Xavier, J.C., 2018. Choosing the future of Antarctica. Nature 558, 233-241. doi:10.1038/s41586-018-0173-4

Roe, H.S.J., Shale, D.M., 1979. A new multiple rectangular midwater trawl (RMT $1+8 \mathrm{M})$ and some modifications to the institute of oceanographic sciences' RMT 1+8. Mar Biol 50, 283-288. doi:10.1007/BF00394210

Saunders, R.A., Hill, S.L., Tarling, G.A., Murphy, E.J., 2019. Myctophid Fish (Family Myctophidae) Are Central Consumers in the Food Web of the Scotia Sea (Southern Ocean). Front. Mar. Sci. 6, 142. doi:10.3389/fmars.2019.00530 Seco, J., Roberts, J., Ceia, F.R., Baeta, A., Ramos, J.A., Paiva, V.H., Xavier, J.C., 2015. Distribution, habitat and trophic ecology of Antarctic squid Kondakovia longimana and Moroteuthis knipovitchi: inferences from predators and stable isotopes. Polar Biol. doi:10.1007/s00300-015-1675-2

Seco, J., Xavier, J.C., Brierley, A.S., Bustamante, P., Coelho, J.P., Gregory, S., Fielding, S., Pardal, M.A., Pereira, B., Stowasser, G., Tarling, G.A., Pereira, M.E., 2020a. Mercury levels in Southern Ocean squid: Variability over the last decade. Chemosphere 239, 124785. doi:10.1016/j.chemosphere.2019.124785

Seco, J., Xavier, J.C., Bustamante, P., Coelho, J.P., Saunders, R.A., Ferreira, N., Fielding, S., Pardal, M.A., Stowasser, G., Viana, T., Tarling, G.A., Pereira, M.E., Brierley, A.S., 2020b. Main drivers of mercury levels in Southern Ocean lantern fish Myctophidae. Environ. Pollut. 264, 114711-10. doi:10.1016/j.envpol.2020.114711

Seyboth, E., Groch, K.R., Rosa, L.D., Reid, K., Flores, P.A.C., Secchi, E.R., 2016. Southern Right Whale (Eubalaena australis) Reproductive Success is Influenced by Krill (Euphausia superba) Density and Climate. Scient. Rep. 1-8. doi:10.1038/srep28205

Sidell, B.D., O'Brien, K.M., 2006. When bad things happen to good fish: the loss of hemoglobin and myoglobin expression in Antarctic icefishes. J. Exp. Biol. 209, 1791-1802. doi:10.1242/jeb.02091

Stowasser, G., Atkinson, A., Mcgill, R.A.R., Phillips, R.A., Collins, M.A., Pond, D.W., 2012. Food web dynamics in the Scotia Sea in summer A stable isotope study. Deep Sea Research Part II: Topical Studies in Oceanography 59-60, 208-221.

Tartu, S., Bustamante, P., Goutte, A., Cherel, Y., Weimerskirch, H., Bustnes, J.O., Chastel, O., 2014. Age-Related Mercury Contamination and Relationship with Luteinizing Hormone in a Long-Lived Antarctic Bird. PLoS ONE 9, e103642. doi:10.1371/journal.pone.0103642.t004

Tavares, S., Xavier, J.C., Phillips, R.A., Pereira, M.E., Pardal, M.A., 2013. Influence of age, sex and breeding status on mercury accumulation patterns in the 

wandering albatross Diomedea exulans. Environ. Pollut. 181, 315-320. doi:10.1016/j.envpol.2013.06.032

Thompson, D.R., Bearhop, S., Speakman, J.R., Furness, R.W., 1998. Feathers as a means of monitoring mercury in seabirds: insights from stable isotope analysis. Environ. Pollut. 101, 193-200. doi:10.1016/s0269-7491(98)00078-5

Walton, D., 2013. Antarctica: global science from a Frozen Continent.

Wania, F., Mackay, D., 1996. The global fractionation of persistent organic pollutants. Environ. Sci. Technol. 30, 390.

Ward, D.M., Nislow, K.H., Folt, C.L., 2010. Bioaccumulation syndrome: identifying factors that make some stream food webs prone to elevated mercury bioaccumulation. Ann. N.Y. Acad. Sci. 1195, 62-83. doi:10.1111/j.17496632.2010.05456.x

Xavier, J.C., Croxall, J.P., Reid, K., 2003. Interannual variation in the diets of two albatross species breeding at South Georgia: implications for breeding performance. Ibis 145, 593-610.

Xavier, J.C., Peck, L.S., 2015. Life Beyond the Ice, in: Exploring the Last Continent: an Introduction to Antarctica, Marine Ecosystems in the Southern Ocean. Springer International Publishing, Cham, pp. 229-252. doi:10.1007/978-3-31918947-5_12

Xavier, J.C., Trathan, P.N., Ceia, F.R., Tarling, G.A., Adlard, S., Fox, D., Edwards, E.W.J., Vieira, R.P., Medeiros, R., De Broyer, C., Cherel, Y., 2017. Sexual and individual foraging segregation in Gentoo penguins Pygoscelis papua from the Southern Ocean during an abnormal winter. PLoS ONE 12, e0174850. doi:10.1371/journal.pone.0174850

Xavier, J.C., Velez, N., Trathan, P.N., Cherel, Y., De Broyer, C., Cánovas, F., Seco, J., Ratcliffe, N., Tarling, G.A., 2018. Seasonal prey switching in non-breeding gentoo penguins related to a wintertime environmental anomaly around South Georgia. Polar Biol. 41, 2323-2335. doi:10.1007/s00300-018-2372-8

Yoshinaga, J., Suzuki, T., Hongo, T., Minagawa, M., Ohtsuka, R., Kawabe, T., Inaoka, T., Akimichi, T., 1992. Mercury concentration correlates with the nitrogen stable isotope ratio in the animal food of Papuans. Ecotoxicol. Environ. Saf. 24, 37-45. doi:10.1016/0147-6513(92)90033-Y 
Table 1- Mercury ( $\mathrm{Hg}$ ) concentration, $\delta^{13} \mathrm{C}$ and $\delta^{15} \mathrm{~N}$ values of different species sampled on land or caught in the waters around South Georgia in the 2007/08 austral summer (mean \pm standard deviation). The superscript numbers $\left({ }^{1}\right)$ and letters $\left({ }^{a}\right)$ denotes statistical significance from within the sampling year and comparison between years, respectively.

\begin{tabular}{|c|c|c|c|c|}
\hline Species & $n$ & $H g\left(\mu g g^{-1}\right)$ & $\delta^{15} N(\%)$ & $\delta^{13} C(\% \circ)$ \\
\hline \multicolumn{5}{|c|}{ Zooplankton } \\
\hline Parandania boecki & 15 & $0.02 \pm 0.01^{1, a}$ & $8.34 \pm 0.42^{1, a}$ & $-21.90 \pm 1.70^{1, \mathrm{a}}$ \\
\hline Euphausia triacantha & 20 & $0.03 \pm 0.01^{1, a}$ & $6.71 \pm 0.55^{1,2, a}$ & $-22.15 \pm 1.47^{1, \mathrm{a}}$ \\
\hline Gigantocypris sp. & 15 & $0.03 \pm 0.01^{1, a}$ & $8.81 \pm 0.98^{1,2, a}$ & $-22.27 \pm 0.41^{1, a}$ \\
\hline Salpa thompsoni & 10 & $0.03 \pm 0.01^{1}$ & $4.40 \pm 0.22^{1,2}$ & $-23.75 \pm 1.32^{1}$ \\
\hline Tomopteris sp. & 6 & $0.03 \pm 0.01^{1}$ & $7.25 \pm 0.73^{1,2}$ & $-22.64 \pm 0.65^{1}$ \\
\hline Euphausia superba & 20 & $0.04 \pm 0.02^{1, a}$ & $3.47 \pm 2.45^{2, a}$ & $-23.17 \pm 2.86^{1, a}$ \\
\hline Themisto gaudichaudii & 20 & $0.04 \pm 0.02^{1, a}$ & $5.86 \pm 0.56^{1,2, a}$ & $-24.10 \pm 0.45^{1, a}$ \\
\hline Thysanoessa sp. & 20 & $0.05 \pm 0.01^{1, a}$ & $6.94 \pm 0.32^{1,2, a}$ & $-23.99 \pm 0.71^{1, a}$ \\
\hline Sagitta sp. & 3 & $0.06 \pm 0.01^{1}$ & $8.21 \pm 0.84^{1,2}$ & $-22.97 \pm 1.03^{1}$ \\
\hline \multicolumn{5}{|c|}{ Squid } \\
\hline Slosarczykovia circumantarctica & 5 & $0.02 \pm 0.01^{1, a}$ & $6.72 \pm 0.25^{1, \mathrm{a}}$ & $-21.64 \pm 1.88^{1, b}$ \\
\hline Galiteuthis glacialis & 5 & $0.09 \pm 0.01^{1, a}$ & $7.66 \pm 1.49^{1, a}$ & $-23.58 \pm 1.05^{1, a}$ \\
\hline \multicolumn{5}{|c|}{ Myctophid fish } \\
\hline Krefftichthys anderssoni & 5 & $0.04 \pm 0.01^{2, a}$ & $8.21 \pm 0.95^{1, a}$ & $-20.96 \pm 0.19^{1, a}$ \\
\hline Protomyctophum bolini & 5 & $0.09 \pm 0.01^{2, a}$ & $8.87 \pm 0.88^{1, a}$ & $-21.82 \pm 2.13^{1, a}$ \\
\hline Electrona carlsbergi & 5 & $0.14 \pm 0.02^{2,3}$ & $8.31 \pm 1.12^{1}$ & $-20.91 \pm 0.83^{1}$ \\
\hline Gymnoscopelus braueri & 5 & $0.16 \pm 0.03^{2,3, a}$ & $9.77 \pm 0.56^{1, a}$ & $-23.63 \pm 0.44^{1, a}$ \\
\hline Gymnoscopelus opisthopterus & 5 & $0.16 \pm 0.06^{2,3}$ & $10.81 \pm 0.15^{1}$ & $-23.12 \pm 0.96^{1}$ \\
\hline Electrona antarctica & 5 & $0.18 \pm 0.09^{2,3, b}$ & $8.64 \pm 0.96^{1, a}$ & $-24.91 \pm 0.66^{1, a}$ \\
\hline Gymnoscopelus nicholsi & 5 & $0.29 \pm 0.12^{3, a}$ & $8.70 \pm 0.94^{1, a}$ & $-22.00 \pm 1.14^{1, a}$ \\
\hline \multicolumn{5}{|c|}{ Seabirds } \\
\hline Macronectes halli & 5 & $0.47 \pm 0.33^{4, b}$ & $\begin{array}{l}13.07 \pm \\
0.56^{3,4, b}\end{array}$ & $-18.68 \pm 0.87^{2, a}$ \\
\hline Macronectes giganteus & 5 & $0.85 \pm 0.12^{5, b}$ & $11.80 \pm 0.33^{3, a}$ & $-18.23 \pm 0.66^{2,3, b}$ \\
\hline Thalassarche melanophris & 5 & $1.18 \pm 0.46^{5, a}$ & $11.83 \pm 0.19^{3, a}$ & $-17.30 \pm 0.93^{2,3, b}$ \\
\hline Thalassarche chrysostoma & 5 & $1.25 \pm 0.45^{5, a}$ & $12.06 \pm 0.56^{3, a}$ & $-18.22 \pm 1.47^{2,3, b}$ \\
\hline Stercorarius antarcticus & 5 & $2.44 \pm 1.08^{6, a}$ & $\begin{array}{l}12.63 \pm \\
0.54^{3,4, a}\end{array}$ & $-15.59 \pm 0.32^{3, b}$ \\
\hline Diomedea exulans & 5 & $3.28 \pm 0.63^{6, a}$ & $14.83 \pm 0.61^{4, a}$ & $-18.29 \pm 0.42^{2,3, b}$ \\
\hline
\end{tabular}


Table 2- Mercury ( $\mathrm{Hg}$ ) concentration, $\delta^{13} \mathrm{C}$ and $\delta^{15} \mathrm{~N}$ values of different species sampled on land or caught in the waters around South Georgia in the 2016/17 austral summer (mean \pm standard deviation) The superscript numbers $\left({ }^{1}\right)$ and letters (a) denotes statistical significance from within the sampling year and comparison between years, respectively.

\begin{tabular}{|c|c|c|c|c|}
\hline Species & $n$ & $H g\left(\mu g g^{-1}\right)$ & $\delta^{15} N(\%)$ & $\delta^{13} \mathrm{C}(\%)$ \\
\hline POM & $\begin{array}{l}12 \\
Z o\end{array}$ & $\begin{array}{l}0.0005 \pm \\
0.0002 \\
\text { olankton }\end{array}$ & n.a. & n.a. \\
\hline Euphausia superba & 30 & $0.01 \pm 0.003^{1, a}$ & $3.38 \pm 0.38^{1, a}$ & $-24.98 \pm 0.66^{1, a}$ \\
\hline Euphausia vallentini & 30 & $0.01 \pm 0.03^{2}$ & $3.00 \pm 0.78^{1}$ & $-21.60 \pm 0.18^{1}$ \\
\hline Thysanoessa sp. & 40 & $0.02 \pm 0.01^{2, a}$ & $5.62 \pm 0.29^{2, a}$ & $-23.99 \pm 0.64^{1, a}$ \\
\hline Euphausia triacantha & 30 & $0.02 \pm 0.03^{2, a}$ & $7.08 \pm 0.62^{2, a}$ & $-22.72 \pm 0.17^{1, a}$ \\
\hline Euphausia frigida & 35 & $0.05 \pm 0.01^{2}$ & $5.94 \pm 0.04^{2}$ & $-21.16 \pm 0.48^{1}$ \\
\hline Themisto gaudichaudii & 40 & $0.06 \pm 0.02^{2, a}$ & $5.61 \pm 0.79^{2, a}$ & $-22.46 \pm 0.52^{1, a}$ \\
\hline Gigantocypris sp. & 20 & $0.07 \pm 0.01^{2, a}$ & $7.07 \pm 1.09^{2, a}$ & $-24.71 \pm 0.35^{1, a}$ \\
\hline Euphausia spinifera & 20 & $0.07 \pm 0.02^{2}$ & $5.05 \pm 0.66^{2}$ & $-22.79 \pm 0.09^{1}$ \\
\hline Parandania boecki & 30 & $0.12 \pm 0.03^{2, a}$ & $7.55 \pm 0.28^{2, a}$ & $-21.82 \pm 1.90^{1, a}$ \\
\hline \multicolumn{5}{|c|}{ Squid } \\
\hline $\begin{array}{r}\text { Slosarczykovia } \\
\text { circumantarctica }\end{array}$ & 5 & $0.01 \pm 0.01^{2, a}$ & $6.23 \pm 0.78^{2, a}$ & $-23.13 \pm 0.43^{1, b}$ \\
\hline Galiteuthis glacialis & 5 & $0.02 \pm 0.01^{2, a}$ & $7.40 \pm 0.09^{2, a}$ & $-24.68 \pm 0.49^{1, a}$ \\
\hline \multicolumn{5}{|c|}{ Myctophid fish } \\
\hline Krefftichthys anderssoni & 5 & $0.05 \pm 0.01^{2, a}$ & $8.48 \pm 0.50^{2, a}$ & $-23.02 \pm 0.10^{1, a}$ \\
\hline Protomyctophum bolini & 5 & $0.10 \pm 0.03^{2, a}$ & $7.98 \pm 0.75^{2, a}$ & $-23.43 \pm 0.70^{1, a}$ \\
\hline Gymnoscopelus braueri & 5 & $0.12 \pm 0.06^{2,3, a}$ & $9.58 \pm 0.97^{2, a}$ & $-24.37 \pm 0.61^{1, a}$ \\
\hline Electrona antarctica & 5 & $0.12 \pm 0.07^{2,3, b}$ & $7.41 \pm 0.72^{2, a}$ & $-24.54 \pm 0.34^{1, \mathrm{a}}$ \\
\hline Gymnoscopelus nicholsi & 5 & $0.30 \pm 0.17^{3, a}$ & $9.73 \pm 0.03^{2, a}$ & $-20.74 \pm 0.34^{1, a}$ \\
\hline \multicolumn{5}{|c|}{ Notothenioid fish } \\
\hline Champsocephalus gunnari & 11 & $0.02 \pm 0.01^{2}$ & $9.18 \pm 0.56^{2}$ & $-22.95 \pm 0.44^{1}$ \\
\hline Patagonotothen guntheri & 5 & $0.10 \pm 0.03^{2,3}$ & $8.34 \pm 0.56^{2}$ & $-23.43 \pm 0.32^{1,2}$ \\
\hline Chaenocephalus aceratus & 5 & $0.11 \pm 0.02^{2,3}$ & $10.79 \pm 1.12^{2,3}$ & $-21.66 \pm 0.50^{1,2}$ \\
\hline Notothenia gibberifrons & 8 & $0.18 \pm 0.07^{3}$ & $11.30 \pm 0.54^{3}$ & $-19.93 \pm 0.78^{2}$ \\
\hline Notothenia rossii & 8 & $0.18 \pm 0.08^{3}$ & $10.78 \pm 1.67^{2,3}$ & $-21.39 \pm 0.58^{1,2}$ \\
\hline Dissostichus eleginoides & 5 & $0.20 \pm 0.06^{3}$ & $11.86 \pm 0.75^{3}$ & $-21.76 \pm 0.77^{1}$ \\
\hline \multicolumn{5}{|c|}{ Seabirds } \\
\hline Pachyptila desolata & 5 & $0.22 \pm 0.14^{3}$ & $8.59 \pm 0.78^{2}$ & $-21.58 \pm 0.73^{3}$ \\
\hline Halobaena caerulea & 5 & $0.62 \pm 0.23^{3}$ & $9.25 \pm 0.50^{2,3}$ & $-21.14 \pm 0.67^{3}$ \\
\hline Thalassarche chrysostoma & 5 & $1.43 \pm 0.50^{4, a}$ & $11.78 \pm 0.67^{3, a}$ & $-19.91 \pm 0.40^{3,4, b}$ \\
\hline Thalassarche melanophris & 5 & $1.51 \pm 0.46^{4, a}$ & $\begin{array}{l}11.52 \pm \\
0.35^{2,3, a}\end{array}$ & $-20.32 \pm 0.63^{3,4, b}$ \\
\hline Macronectes giganteus & 5 & $1.68 \pm 0.27^{4, b}$ & $\begin{array}{l}11.52 \pm \\
0.41^{2,3, a}\end{array}$ & $-20.46 \pm 0.38^{3,4, b}$ \\
\hline Macronectes halli & 5 & $2.05 \pm 0.80^{4, b}$ & $\begin{array}{l}11.58 \pm \\
0.65^{2,3, b}\end{array}$ & $-19.69 \pm 1.12^{3,4, a}$ \\
\hline Stercorarius antarcticus & 5 & $3.88 \pm 2.41^{5, a}$ & $11.88 \pm 1.13^{3, a}$ & $-18.79 \pm 0.90^{4, b}$ \\
\hline
\end{tabular}


Figure Captions

Figure 1 - Mercury concentration on a log 10 scale versus $\delta^{15} \mathrm{~N}$ for zooplankton (whole individuals), myctophid fish (muscle) and seabirds (feathers) that were caught in $2007 / 08\left(Y=0.2028^{*} X-2.6008\right)$ and in $2016 / 17(Y=$ $0.2782 * X-3.0960)$

Figure 2 - Illustrations of the South Georgia food web in years with high Antarctic krill abundance (left - A) and in years with low Antarctic krill abundance (right - B). Shaded/clear areas represent different trophic levels, boxes represent mercury concentrations (more $\mathrm{Hg}$ - higher concentration). 
Figure 1

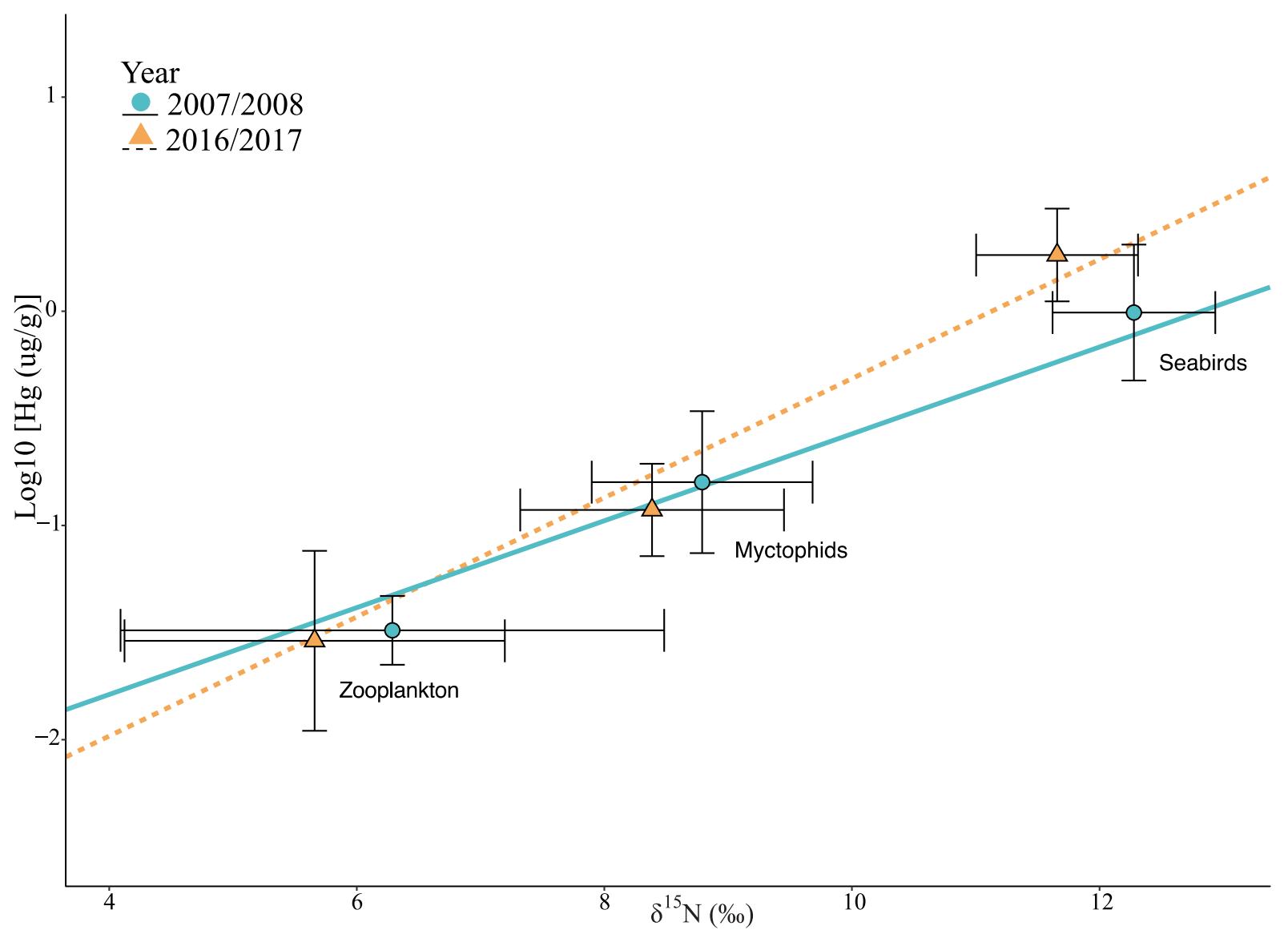


Figure 2

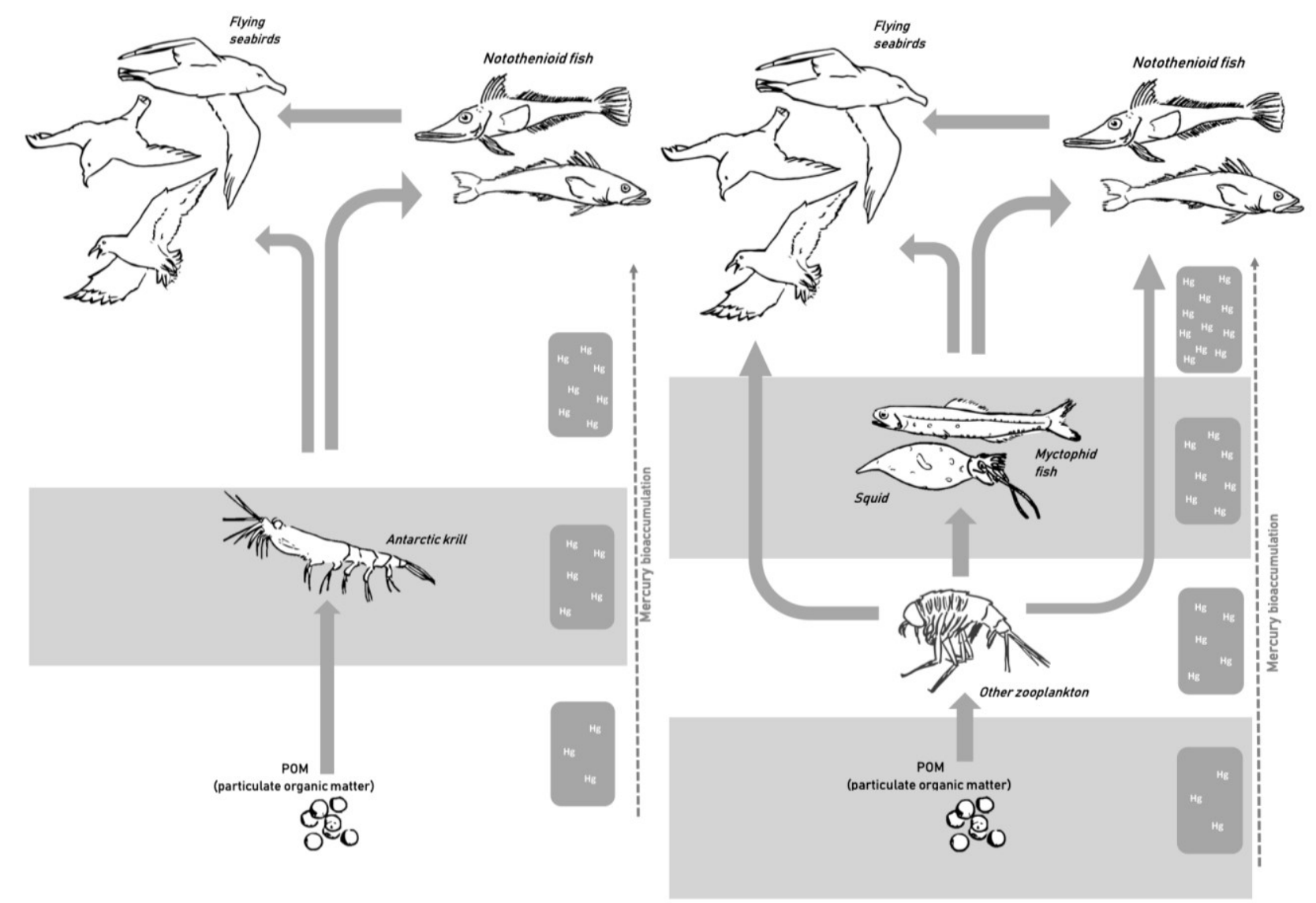

